Subendocardial Infarction. - The criteria mentioned above were used. In both subepicardial and subendocardial infarction a progressive reduction of the height of the $\mathbf{R}$ wave also occurred frequently.

\section{CRITERIA FOR LOCATION OF TRANSMURAL INFARCTION}

(1) Diaphragmatic Infarction.-A $Q$ wave of $>0.04 \mathrm{sec}$ in aVF and $>25 \%$ of the amplitude of $R$ in aVF; a $Q$ wave of $>0.03 \mathrm{sec}$ and ST-T evolution in aVF, typical of myocardial infarction. An increase in the $Q$ duration in aVF with at least $0.02 \mathrm{sec}$ with typical ST-T segment changes, in the presence of a $Q$ wave in $\mathrm{L} 2$ of $>0.02 \mathrm{sec}$. The appearance of $Q$ wave in $\mathrm{L} 3>5 \mathrm{~mm}$ deep and $>0.04 \mathrm{sec}$ duration in the presence of an $R$ wave in $L 3>1 \mathrm{~mm}$ (without a pathological $Q$ wave in aVF). A $Q$ wave of $>0.05 \mathrm{sec}$ and $>33 \%$ of the $R$ wave in aVF in the presence of a complete left bundle-branch block.

(2) Posterolateral Infarction.-A $Q$ wave $>0.03 \mathrm{sec}$. $Q$ wave $>0.02$ sec plus typical sequential ST-T segment changes and an $R$ loss of $>1 / 3$ in V6 (only V6 was used in the evaluation, since more lateral leads were not available in the electrocardiograms from some centres).

(3) Anteroseptal Infarction.-A QS wave in V1-V2 or V1-V4. Decreasing R V1 to V3 in the presence of sequential ST-T segment changes.

(4) Anterior Infarction.-A QS wave in either V2-V3, V2-V4, or V2-V5. A $Q$ wave $>0.03 \mathrm{sec}$ in at least two consecutive leads between $\mathrm{V} 2$ and $\mathrm{V} 5$.

(5) High Lateral Infarction.-A $Q$ wave $>0.03 \mathrm{sec}$ with a $\mathbf{R}$ wave $>3 \mathrm{~mm}$ in aVL, with sequential ST-T wave changes. A $Q$ wave $>0.03 \mathrm{sec}$ in aVL in the presence of a $Q$ wave in V5, V6, and complete left bundle-branch block.

(6) Posterior Infarction.-A Q wave $>0.03 \mathrm{sec}$ in V6 with an $\mathbf{R}$ wave $>5 \mathrm{~mm}$ and an $S$ wave $<1 \mathrm{~mm}$ in Vl, in the absence of a pathological $Q$ wave in $\mathrm{D} 3$, aVF.

(7) Transmural Infarction in Presence of Wolff-ParkinsonWhite Syndrome.-An R loss of $>50 \%$ in leads V2-V4 in the presence of typical evolution of a Pardee curve. The development of $Q$ waves was prevented by the existence of a pre-excitation wave.

The infarctions described under 1 and 6 have been classified as diaphragmatic (inferior) infarctions, and those described under 3 , 4 , and 5 as anterior infarctions.
CONDUCTION DISTURBANCES

The conduction disturbances noted were: A-V block first degree, A-V block second degree, A-V block third degree, complete A-V block, complete right bundle-branch block, and complete left bundle-branch block; left parietal block $(R / S<0.5$ in L 2 in the absence of an $S$ wave in a VL and a QRS duration $<0.12 \mathrm{sec}$ ); and right parietal block (terminal $R$ wave V1 of at least $1 \mathrm{~mm}$, with QRS duration $<0 \cdot 12 \mathrm{sec}$ ).

\section{RHYTHM DISTURBANCES}

Rhythm disturbances noted were nodal rhythm, auricular fibrillation, auricular flutter, paroxysmal auricular tachycardia, and ventricular tachycardia.

\section{References}

Amery, A., Roeber, G., Vermeulen, H. J., and Verstraete, M. (1969) Acta Medcia Scandinavica, Suppl. No. 505.

Bailey, N. T. (1959). Statistical Methods in Biology. London, English University Press.

Bhapkar, V. P., and Koch, G. C. (1968). Biometrics, 24, 567.

Brown, K. W. G., and MacMillan, R. L. (1965). Anticoagulent Therapy in Ischemic Heart Disease, p. 70. New York and London, Grune and Stratton.

Chapman, I. (1968). Fournal of Mount Sinai Hospital, N.Y., 35, 149.

Edwards, J. (1969). Circulation, 40, Suppl. No. 4, p. 5.

Fletcher, A. P. (1969). In Thrombosis, ed. S. Sherry, K. M. Brinkhous E. Genton, and J. M. Stengle, p. 710, Washington D.C., National Academy. of Sciences.

Gupta, D. K., Young, R., Jewitt, D. E., Hartog, M., and Opie, L. H.

Kendall, M. G. G., and Stuart, A. (1963). The Advanced Theory of Statistics, vol. 1, Appendix table 6, London, Griffin

Kagan, A., Livsic, A. M., Sternby, N., and Vihert, A. M. (1968). Lancet, 2, 1199.

Meadows, R. (1965). Medical fournal of Australia, 2, 409.

Rosso, J. V., Friesinger, G. C., Margolis, S., and Ross, R. S. (1970). Lancet, 2, 1271 .

Schmutzler, R., et al. (1966). Deutsche Medizinische Wochenschrift, 91, 581.

Schmutzler, R., et al. (1970). Fibrinolytic Therapy of Acute Myocardial Infarction. XIII International Congress of Haematology, Munich, 2-8 August 1970.

Simborg, D. W., Ross, R. G., Lewis, K. B., and Shepard, R. H. (1966). Fournal of the American Medical Association, 197, 867.

\title{
Relationship between Plasma Level and Therapeutic Effect of Nortriptyline
}

\author{
MARIE ÅSBERG， BORJE CRÖNHOLM， FOLKE SJÖQVIST， DICK TUCK
}

British Medical fournal, 1971, 3, 331-334

\section{Summary}

The relationship between plasma concentration of nortriptyline and therapeutic effect after two weeks' treatment with the drug was investigated in 29 psychiatric inpatients. Endogenous depression was diagnosed in all patients. Amelioration of depressive symptoms was estimated as reduction in score on a

\footnotetext{
Department of Psychiatry, Karolinska Sjukhuset, S-104 01 Stockholm, Sweden

MARIE ASBERG, M.L., Registrar

BORJE CRONHOLM, M.D., Professor

DICK TUCK, M.L., Registrar

The Medical School, Linkoping, Sweden

FOLKE SJÖQVIST, M.D., Professor of Clinical Pharmacology
}

rating scale, based on a psychiatric interview. Amelioration was not correlated to the patient's sex or age. There was a curved relationship between plasma level of nortriptyline and therapeutic effect. Amelioration was most pronounced in the intermediate plasma level range (50-139 ng nortriptyline/ml plasma) and was slight both at lower and at higher plasma levels. This type of relationship may be due to the dual action of tricyclic antidepressants which has been found in animal experiments. On larger dosages a phenothiazine-like blockade of the monoaminergic receptor is added to the blockade of monoamine reuptake thought to be related to the antidepressant action of the drugs.

This study thus suggests two possible reasons for a therapeutic failure with nortriptyline: a too low or a too high plasma level. The large individual variation in the pharmacokinetics of the tricyclic antidepressants makes prediction of plasma level from dosage in a given individual virtually impossible without knowledge of rate of elimination and apparent 
volume of distribution. Hence monitoring plasma levels may be a way to increase the efficacy of treatment with these drugs.

\section{Introduction}

The antidepressant effect of tricyclic thymoleptic drugs has varied in different investigations, but an unsatisfactory response has usually been reported in about $40 \%$ of all patients studied (Bennet, 1967). Electric convulsion treatment has generally been regarded as superior, at least in severe depressions, with a successful outcome in about $80 \%$ (Bennet, 1967). This treatment has, however, certain disadvantages (GranvilleGrossman, 1971).

Lack of therapeutic effect of a drug may obviously have many causes, one being an inadequate concentration at the receptor site. Investigations in psychiatric patients (Hammer et al., 1967; Sjöqvist et al., 1968) and healthy volunteers (Alexanderson et al., 1969; Åsberg et al., 1971) have consistently shown between individuals a very large variation in plasma concentrations of desmethylimipramine and nortriptyline, in spite of equal dosage. A correlation has been shown between the plasma level of nortriptyline and subjective side effects (Åsberg et al., 1970, 1971). The aim of this study was to investigate the influence of the variation in plasma concentrations on the antidepressant effect of nortriptyline.

\section{Patients and Methods}

Thirty-two inpatients (10 men and 22 women) were studied. The mean age of the men was $42 \cdot 0$ years, range $25-56$, standard deviation 10.6; mean age for women was 54.6 years, range 32-76, standard diviation 13.6. All patients were diagnosed as "endogenously" depressed. Endogenous depression was defined as a disease characterized by the following features: (1) lowering of mood, usually without obvious psychological cause; (2) retardation; (3) diurnal variation of symptoms with amelioration in the afternoon; and (4) early awakening, in accordance with the criteria of Cronholm and Ottosson (1960).

Drug Regimen.-Nortriptyline hydrochloride (Sensaval) was given in dosages varying from 25 to $75 \mathrm{mg}$ of the base thrice daily by mouth after a placebo period of four to seven days. The dosage was kept constant for each patient during the study, and the individual dosage levels were chosen without regard to severity of depression. The placebo tablets consisted of lactose and were of the same external appearance as the active drug. The tablets were given at $05.00,14.00$, and 22.00 hours, and the patients were routinely observed to ingest the drug. With the exception of hypnotics (pentobarbitone or glutethimide) and occasional doses of diazepam, no additional medication was allowed. Blood and urine analyses for barbiturates, phenothiazines, and meprobamate were made during the placebo period and every other week during nortriptyline therapy. The results did not deviate from what could be expected from the prescribed treatment.

Determination of Plasma Concentrations of Nortriptyline.Plasma concentrations of nortriptyline were determined during the placebo period and twice weekly during treatment with nortriptyline according to the principles of Hammer and Brodie (1967) as further described by Sjöqvist et al. (1969). Blood samples were drawn at 13.00 hours, collected in heparinized tubes, stored at $4^{\circ} \mathrm{C}$, and centrifuged within one hour at $600 \mathrm{~g}$. Plasma duplicates, $2 \mathrm{ml}$ each, were acidified with $0.5 \mathrm{ml}$ of $0.1 \mathrm{~N} \mathrm{HCl}$ and stored frozen at $-20^{\circ} \mathrm{C}$ until analysed.

Ratings.-Patients were rated for severity of depression during the placebo period and once weekly during active therapy on a slightly modified version of a rating scale designed by Cronholm and Ottosson (1960). The rating was performed by two psychiatrists in a joint interview. They were kept aware of the plasma concentrations of nortriptyline until the study was finished. The difference between depression score during placebo and active treatment ("amelioration score") was used to estimate therapeutic effect.

Statistical Methods.-Psychiatric rating scales are usually considered to be ordinal scales. Hence non-parametric procedures are the most appropriate for statistical analysis (Siegel, 1956). The following methods were used: (1) Spearman's rank correlation for the relationship between age and therapeutic effect; (2) Fisher's exact probability test for the association between sex and therapeutic effect; and (3) Kruskal-Wallis's one-way analysis of variance (with correction for ties) for the relationship between therapeutic effect and plasma level (Siegel, 1956).

\section{Results}

General Outcome.-A few patients recovered during the placebo period and were immediately withdrawn from the study. One patient had significant concentrations of nortriptyline in plasma (cf. Asberg et al., 1970) during the placebo period and was excluded from further calculations. All the remaining 32 patients were able to continue in the study for two weeks but after that time a few of them had to be withdrawn. There were two reasons for withdrawal: (1) lack of effect or worsening of depressive symptoms, necessitating alternative treatment, and (2) amelioration of symptoms to such an extent that the patient did not wish to remain in hospital. The present report is concerned only with results during the first two weeks. Three women became hypomanic. Since hypomania is more likely to be another manifestation of affective disorder than return to mental health, the amelioration score on the depression rating scale would give a misleading estimate of therapeutic effect, and these patients were excluded from all calculations. One patient made a suicidal attempt during the second week which made formal rating impossible. Plasma samples were, however, secured, and the patient was assigned an amelioration score of zero. Full details of the results are shown in Table I.

Plasma Levels of Nortriptyline.-The range of plasma levels was 32-164 (mean 90.1, S.D. 40.1) $\mathrm{ng} / \mathrm{ml}$. In this material

TABLE I-Dosages, Nortriptyline Plasma Concentrations, and Scores on Depression Rating Scale

\begin{tabular}{|c|c|c|c|c|c|c|}
\hline $\begin{array}{l}\text { Case } \\
\text { No. }\end{array}$ & $\begin{array}{c}\text { Sex and } \\
\text { Age }\end{array}$ & $\begin{array}{l}\text { Dosage of } \\
\text { Nortripty- } \\
\text { line (mg/ } \\
\text { kg body } \\
\text { weight) }\end{array}$ & $\begin{array}{l}\text { Plasma Con- } \\
\text { centration of } \\
\text { Nortriptyline } \\
\quad(\mathrm{ng} / \mathrm{ml})\end{array}$ & $\begin{array}{c}\text { Depression } \\
\text { Score } \\
\text { during } \\
\text { Placebo } \\
\text { Treatment }\end{array}$ & \begin{tabular}{|l} 
Depression \\
Score \\
2nd \\
Week
\end{tabular} & $\begin{array}{c}\text { Ameliol- } \\
\text { ration } \\
\text { Score }\end{array}$ \\
\hline $\begin{array}{l}1 \\
2 \\
3 \\
4 \\
5 \\
6\end{array}$ & $\begin{array}{ll}\text { F. } & 35 \\
\text { F. } & 43 \\
\text { M. } & 38 \\
\text { M. } & 25 \\
\text { F. } & 57\end{array}$ & $\begin{array}{l}3.66 \\
1.32 \\
2.66 \\
2.18 \\
3.95\end{array}$ & $\begin{array}{r}121 \\
33 \\
57 \\
59 \\
132\end{array}$ & $\begin{array}{l}14 \\
10 \\
15 \\
14 \\
14 \cdot 5\end{array}$ & $\begin{array}{c}7 \cdot 5 \\
14 \\
7 \\
6 \\
10\end{array}$ & $\begin{array}{l}6 \cdot 5 \\
-4 \\
8 \\
8 \\
4 \cdot 5\end{array}$ \\
\hline $\begin{array}{r}7 \\
8 \\
9 \\
10\end{array}$ & $\begin{array}{ll}\text { M. } & 42 \\
\text { F. } & 72 \\
\text { F. } & 35 \\
\text { F. } & 69 \\
\text { F. } & 38\end{array}$ & $\begin{array}{l}1 \cdot 85 \\
2 \cdot 34 \\
2 \cdot 75 \\
2 \cdot 70 \\
2 \cdot 03\end{array}$ & $\begin{array}{l}62 \\
52 \\
98 \\
75 \\
69\end{array}$ & $\begin{array}{l}16 \\
11 \\
19 \\
16 \\
14 \cdot 5\end{array}$ & $\begin{array}{r}13 \\
4 \\
12 \\
12 \\
10\end{array}$ & $\begin{array}{l}3 \\
8 \\
7 \\
4 \\
4 \cdot 5\end{array}$ \\
\hline $\begin{array}{l}11 \\
12 \\
13 \\
14 \\
15\end{array}$ & $\begin{array}{ll}\text { M. } & 56 \\
\text { M. } & 46 \\
\text { M. } & 43 \\
\text { F. } & 32 \\
\text { M. } & 51\end{array}$ & $\begin{array}{l}2 \cdot 22 \\
3.41 \\
2 \cdot 00 \\
1 \cdot 78 \\
1 \cdot 74\end{array}$ & $\begin{array}{r}49 \\
67 \\
43 \\
49 \\
150\end{array}$ & $\begin{array}{l}12 \\
10 \cdot 5 \\
6 \\
18 \\
9\end{array}$ & $\begin{array}{c}9 \\
2 \cdot 5 \\
4 \cdot 5 \\
16 \cdot 5 \\
2\end{array}$ & $\begin{array}{l}3 \\
8 \\
1.5 \\
1.5 \\
7\end{array}$ \\
\hline $\begin{array}{l}16 \\
17 \\
18 \\
19 \\
20\end{array}$ & $\begin{array}{ll}\text { F. } & 54 \\
\text { F. } & 59 \\
\text { F. } & 68 \\
\text { F. } & 71 \\
\text { M. } & 53\end{array}$ & $\begin{array}{l}2 \cdot 72 \\
2 \cdot 47 \\
2 \cdot 27 \\
3 \cdot 06 \\
1 \cdot 03\end{array}$ & $\begin{array}{r}145 \\
78 \\
83 \\
148 \\
93\end{array}$ & $\begin{array}{l}17 \\
8 \cdot 5 \\
13 \\
10 \\
13.5\end{array}$ & $\begin{array}{c}19 \\
1.5 \\
6 \\
13 \\
5\end{array}$ & $\begin{array}{c}-2 \\
7 \\
7 \\
-3 \\
8 \cdot 5\end{array}$ \\
\hline $\begin{array}{l}21 \\
22 \\
23 \\
24 \\
25\end{array}$ & $\begin{array}{ll}\text { M. } & 41 \\
\text { F. } & 56 \\
\text { F. } & 61 \\
\text { F. } & 58 \\
\text { F. } & 39\end{array}$ & $\begin{array}{l}1 \cdot 93 \\
2 \cdot 16 \\
2 \cdot 34 \\
2 \cdot 88 \\
4 \cdot 02\end{array}$ & $\begin{array}{r}64 \\
96 \\
64 \\
147 \\
131\end{array}$ & $\begin{array}{l}10 \\
7 \\
11 \\
12.5 \\
11.5\end{array}$ & $\begin{array}{c}1 \\
5 \\
9 \\
12.5 \\
8.5\end{array}$ & $\begin{array}{l}9 \\
2 \\
2 \\
0 \\
3\end{array}$ \\
\hline $\begin{array}{l}26 \\
27 \\
28 \\
29\end{array}$ & $\begin{array}{ll}\text { M. } & 25 \\
\text { F. } & 56 \\
\text { F. } & 62 \\
\text { F. } & 72\end{array}$ & $\begin{array}{l}1.12 \\
2.35 \\
3.01 \\
3.00\end{array}$ & $\begin{array}{r}32 \\
128 \\
164 \\
124\end{array}$ & $\begin{array}{r}19 \\
11 \\
6 \\
19\end{array}$ & $\begin{array}{c}-* \\
11 \cdot 5 \\
2 \\
7.5\end{array}$ & $\begin{array}{c}0^{*} \\
-0.5 \\
4 \\
11.5\end{array}$ \\
\hline
\end{tabular}

*The patient made a suicidal attempt during the second week. Formal rating was impossible, and the patient was assigned an amelioration score of zero. 
there was a significant difference in plasma concentration of nortriptyline between men and women (Table II). This was largely due to variation in dosage and body weight. There was a significant regression of plasma nortriptyline concentration (y) on dosage in $\mathrm{mg} / \mathrm{kg}$ body weight ( $x$ ) (regression coefficient $\mathrm{b}=29.8, t(\mathrm{~b})=3.50$, D.F. 27). After adjustment of all plasma concentrations to a standard dosage of $2.45 \mathrm{mg} / \mathrm{kg}$ body weight daily, by using the computed regression coefficient, there was no significant difference between means for men and women (Table II) nor any significant correlation with age $(r=0.32$, $t(\mathrm{r})=1.75)$.

Therapeutic Effect.-There was no correlation between therapeutic effect and age $(r=0.00)$ nor any association between outcome (below or above median) and the patient's sex $(\mathrm{P}=0.25)$.

TABLE II-Plasma Concentrations of Nortriptyline for Men and Women

\begin{tabular}{|c|c|c|c|c|c|c|}
\hline & & \multirow[b]{2}{*}{$\mathrm{n}$} & \multicolumn{4}{|c|}{ Nortriptyline in Plasma $(\mathrm{ng} / \mathrm{ml})$} \\
\hline & & & Mean & S.D. & $t$ & $\mathbf{P}$ \\
\hline \multirow[t]{3}{*}{$\begin{array}{l}\text { Men... } \\
\text { Women }\end{array}$} & $\because$ & $\begin{array}{l}10 \\
19\end{array}$ & $\begin{array}{r}67 \cdot 6 \\
101 \cdot 9\end{array}$ & $\begin{array}{l}33 \cdot 1 \\
39 \cdot 0\end{array}$ & $2 \cdot 37$ & $<0.05$ \\
\hline & & \multirow{2}{*}{$\mathbf{n}$} & \multicolumn{4}{|c|}{$\begin{array}{l}\text { Nortriptyline in Plasma }(\mathrm{ng} / \mathrm{ml}) \text {, Adjusted to a } \\
\text { Standard Dosage of } 2.45 \mathrm{mg} / \mathrm{kg} \text { body weight } / \text { day* }\end{array}$} \\
\hline & & & Mean & S.D. & $t$ & $\mathbf{P}$ \\
\hline $\begin{array}{l}\text { Men... } \\
\text { Women }\end{array}$ & $\because$ & $\begin{array}{l}10 \\
19\end{array}$ & $\begin{array}{l}80 \cdot 5 \\
95 \cdot 2\end{array}$ & $\begin{array}{l}41 \cdot 2 \\
28 \cdot 1\end{array}$ & $1 \cdot 14$ & N.S. \\
\hline
\end{tabular}

$\mathbf{n}=$ Number of patients. S.D. $=$ Standard deviation. N.S. $=$ Not significant. $\mathrm{n}$
*Using a computed regression coefficient as explained in the text.

Relation between Plasma Levels of Nortriptyline and Therapeutic Effect.-The amelioration scores for patients in different plasma level intervals are shown in the Chart. There was a curved relationship between plasma level of nortriptyline and antidepressant effect. The therapeutic effect was slight in patients with very low and very high plasma levels of nortriptyline while those in the intermediate concentration range showed a more pronounced amelioration. There was a significant difference in therapeutic effect between the three plasma level classes "low" ( $\leqslant 49 \mathrm{ng} / \mathrm{ml})$, "intermediate" (50-139 $\mathrm{ng} /$ $\mathrm{ml})$, and "high" $(\geqslant 140 \mathrm{ng} / \mathrm{ml})\left(\chi^{2}=10.89\right.$, D.F. $=2$; $\mathbf{P}<0.01$ )

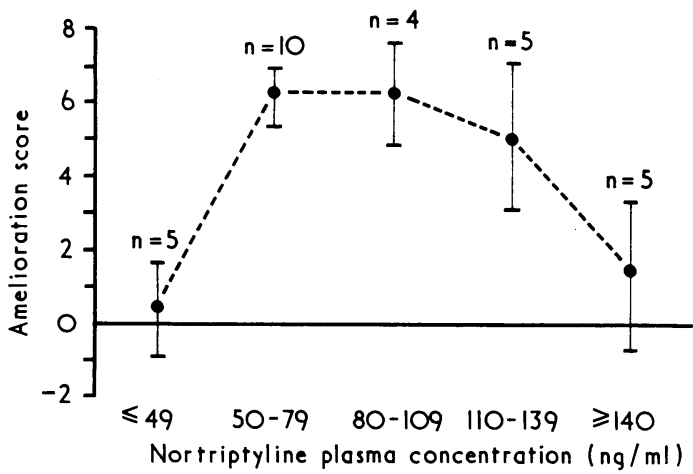

Mean and standard error of amelioration score for different intervals of plasma concentration of nortriptyline. $n=$ Number of patients in each group.

\section{Discussion}

Reports on the relationship between the pharmacokinetics of modern psychotropic drugs and their effect in man are scarce. For nortriptyline, however, a correlation has been shown to exist between its action on peripheral, adrenergic neurons and the steady-state plasma concentration of the drug (Freyschuss et al., 1970). After two weeks' treatment the plasma and receptor compartments in the central nervous system are presumably in equilibrium so far as distribution and elimination of the drug are concerned.

A curved relationship between plasma level of nortriptyline and therapeutic effect, with less response to both extremely low and extremely high plasma levels of the drug, could be explained on the basis of the monoamine hypothesis of depressive disorders. It is generally assumed that the therapeutic action of the tricyclic antidepressants is related to their capacity of inhibiting reuptake of transmitter substances in central monoaminergic neurons, thereby increasing the amount of monoamine available at the receptor (Carlsson, 1965; Schildkraut and Kety, 1967). Tricyclic antidepressant drugs have been shown to exert a dual action on the peripheral adrenergic neuron. In lower dosages adrenergic effects are potentiated, in the higher dosage range this effect disappears or is reversed (Haefely et al., 1964; Møller-Nielsen, 1970). This is probably due to a blockade of the adrenergic receptor, similar to that seen with phenothiazine compounds (Sigg et al., 1963).

The observed lack of effect or the worsening of depressive symptoms at higher concentrations of nortriptyline found in the present study may also be compared with the recent reports of severe depression as a side eflect of treatment with slow-release preparations of phenothiazines (de Alarcon and Carney, 1969).

A number of factors presumably contribute to the outcome of treatment with antidepressant drugs-for example, type and severity of depression, the tendency to spontaneous remission, and pharmacokinetic parameters. The relative importance of these factors and their possible interaction remains to be investigated.

This study suggests two possible reasons for a therapeutic failure with antidepressant drugs: a too low or a too high plasma level. The large variation in plasma concentrations between individuals makes it impossible to predict plasma level from dosage without knowledge of pharmacokinetic parameters-that is, half-time of elimination and apparent volume of distribution (Alexanderson and Sjöqvist, 1971). A very high plasma level is often associated with subjective side effects, but in an individual patient these are notoriously difficult to discern from placebo effects and depressive symptoms. Furthermore, plasma concentration of nortriptyline accounts only for a fraction of the variance in side effects (Asberg et al., 1970). Thus for patients who do not respond satisfactorily on conventional dosages of nortriphyline monitoring the plasma levels of the drug might be rewarding. A methed of calculation of the dosage required for an individual to reach a therapeutic plasma concentration is at present being evaluated in this laboratory.

This study was supported by grants from the Tri-Centennial Fund of the Bank of Sweden, the Swedish Medical Research Council (B 70-21x-1021-05), the National Institutes of Health, Bethecda, Maryland, U.S.A. (G M 13978-05), and by funds from the Karolinska Institutet.

\section{References}

de Alarcon, R., and Carney, M. W. P. (1969). British Medical Fournal, 3, 564. Alexanderson, B., Evans, D. A. P., and Sjöqvist, F. (1969). British Medical Fournal, 4, 764

Alexanderson, B., and Sjöqvist, F. (1971). Annals of the New York Academy of Science. In press.

Åsberg, M., Cronholm, B., Sjöqvist, F., and Tuck, D. (1970). British Medical fournal, 4, 18 .

Åsberg, M., Evans, D. A. P., and Sjöqvist, F. (1971). Fournal of Medical Genetics, 8, 129.

Bennet, I. F. (1967). In Antidepressant Drugs, ed. S. Garattini and M. N. G. Dukes, p. 375. Amsterdam, Excerpta Medica.

Carlsson, A. (1965). In Handbuch der experimentellen Pharmakologie, ed. O. Eichler and A. Farah, vol. 19, p. 529. Berlin, Springer.

Cronholm, B., and Ottosson, J. O. (1960). Acta Psychiatrica Scandinavica, 35, Suppl. No. 145, p. 69 . Freyschuss, U., Sjöqvist, F., and Tuck, D. (1970). Pharmacologia Clinica,
2, 72 . 
Granville-Grossman, K. (1971). In Recent Advances in Clinical Psychiatry, p. 12, Churchill, London.

Haefely, W., Hürlimann, A., and Thoenen, H. (1964). Helvetica Physiologica Acta, 22, 15.

Hammer, W., and Brodie, B. B. (1967). Journal of Pharmacology and Experimental Therapeutics, 157, 503.

Hammer, W., Ideström, C.-M., and Sjöqvist, F. (1967). In Antidepressant Drugs, ed. S. Garattini and M. N. G. Dukes, p. 301. Amsterdam, Excerpta Medica.

Møller-Nielsen, I. (1970). In The Neuroleptics. p. 68. ed. D. P. Bobon, P. A. J. Janssen, and J. Bobon. Basel, Karger.

Schildkraut, J. J., and Kety, S. S. (1967). Science, 156, 21.
Siegel, S. (1956). Nonparametric Statistics for the Behavioral Sciences. New York, McGraw-Hill.

Sigg, E. B., Soffer, L., and Gyermek, L. (1963). Journal of Pharmacology and Experimental Therapeutics, 142,13

Sjöqvist, F. et al., (1968). In Toxicity and Side Effects of Psychotropic Drugs, ed. S. B. de C. Baker, J. R. Boissier, and W. Koll, p. 246. Amsterdam, Excerpta Medica.

Sjöqvist, F., Hammer, W., Borgå, O., and Azarnoff, D. L. (1969). In Collegium Internationale Neuro-psychopharmacologicum: The Present Status of Psychotropic Drugs, ed. A. Cerletti and F. J. Boré, p. 128. Atatus of Psychotropic Drugs,

\title{
Acute Myocardial Infarction: Home and Hospital Treatment
}

\author{
H. G. MATHER, N. G. PEARSON， K. L. Q. READ， D. B. SHAW， G. R. STEED， M. G. THORNE, \\ S. JONES, C. J. GUERRIER, C. D. ERAUT, P. M. McHUGH, N. R. CHOWDHURY, M. H. JAFARY, \\ T. J. WALLACE
}

British Medical fournal, 1971, 3, 334-338

\section{Summary}

This is a preliminary report of a co-operative study of 1,203 episodes of acute myocardial infarction in men under 70 years in four centres in the south west of England. The mortality at 28 days was $15^{\%}$, A comparison is made between home care by the family doctor and hospital treatment initially in an intensive care unit: 343 cases were allocated at random. The randomized groups do not differ significantly in composition with respect to age; past history of angina, infarction, or hypertension; or hypotension when first examined. The mortality rates of the random groups are similar for home and hospital treatment. The group sent electively to hospital contained a higher proportion of initially hypotensive patients whose prognosis was bad wherever treated; those who were not hypotensive fared rather worse in hospital.

For some patients with acute myocardial infarction seen by their general practitioner home care is ethically justified, and the need for general admission to hospital should be reconsidered.

\section{Introduction}

In the past 20 years there has been a rise in the number of deaths ascribed to coronary heart disease. There has been a corresponding increase of interest in its natural history and

Southmead Hospital, Bristol BS10 5NB

S. JONES, M.B., D.C.H., Research Assistant

C. J. GUERRIER, M.B., M.R.C.P., Research Assistant

H. G. MATHER, M.D., F.R.C.P., Consultant Physician

University of Exeter, Exeter

N. G. PEARSON, M.B., B.S., Co-director, Institute of Biometry and Community Medicine

K. L. Q. READ, PH.D., Lecturer in Mathematical Statistics

Royal Devon and Exeter Hospital, Exeter EX1 1PQ

C. D. ERAUT, M.B., B.CH., Research Assistant

P. M. McHUGH, M.B., B.CH., Research Assistant

D. B. SHAW, M.D., M.R.C.P., Consultant Physician

Scott Hospital, Plymouth PL2 2PQ

G. R. STEED, M.D., F.R.C.P., Consultant Physician

T. J. WALLACE, M.B., M.R.C.P., Research Assistant

Torbay Hospital, Torquay TQ2 7AA

N. R. CHOWDHURY, M.B., B.S., Research Assistant

M. H. JAFARY, M.B., B.S., Research Assistant

M. G. THORNE, M.D., F.R.C.P., Consultant Physician treatment, particularly in those nations where expectation of life is greater than 65 years and where a high proportion of deaths below this age is due to this disease. The value of various drugs, the role of the intensive care unit, and the use of special ambulances have been studied, but little information is available on the fate of patients treated at home except for the reports by Wright (1964), Sleet (1968), Nichols (1968), and Fry (1968).

From a retrospective survey of general practices in the south west of England in 1964, Wright found that patients developing acute myocardial infarction were treated in hospital and at home in about equal numbers and that the mortality rates in the two groups were similar. Accordingly, as one of a number of trials related to coronary care considered by a Ministry of Health working party under the chairmanship of Lord Platt, a randomized controlled trial was planned in order to compare the fate of patients treated in hospital, initially in an intensive care unit, with that of patients treated at home. If, indeed, intensive hospital care offered important advantages then there would be a need (1) to revise the present practice of the family doctor, (2) to plan for increased coronary care facilities and beds in hospital and, (3) perhaps to develop special ambulances in order to shorten the interval between the patient developing pain and receiving intensive care.

\section{Plan of Trial}

The trial was confined to men under 70 years of age who had suffered a myocardial infarction within the previous 48 hours. Women were excluded because it was felt that home care would be difficult for social reasons. The trial was started in Bristol in October 1966, in Exeter in July 1967, in Torbay in January 1968, and in Plymouth in April 1968. Local general practitioners were contacted and over half agreed to participate-altogether 458 .

It was planned that where possible the treatment at home or in hospital would be allocated at random in order to avoid bias in selection. The family doctor carried a sealed envelope stipulating home or hospital care, and the decision on whether a patient could be so selected rested entirely with him. The envelopes were numbered and checked to ensure that the allocation had been adhered to. It was accepted that random selection would not be possible in all patients for the following reasons: (a) social conditions might preclude care being given at home, and patients not resident in the area would not be eligible for randomization; $(b)$ patients suffering an attack at work, in the street, or in hospital would most likely be treated in hospital without reference to the general practitioners; (c) patients or relatives might express a strong desire for home 